Anna Sobczak, Ph.D.

Laboratory of Special Education

Faculty of Educational Sciences

University of Lodz, 91-433 Łódź, Smugowa 10/12

Poland

\title{
A SENSE OF MORAL OBLIGATION OF SLIGHTLY MENTALLY HANDICAPPED YOUTH
}

\section{Introduction}

The issue of human moral development has been a subject of interest in many scientific fields for years. Each society has its own clearly defined morality which is expressed by "a set of norms and patterns of behavior that relate to acts recognized in the common mind as good and bad"(H. Muszynski, 1983, p.16). Educators, psychologists, sociologists, and others try to explain how the child acquires moral knowledge, how moral consciousness is shaped and what causes them to act, or not, by generally accepted standards. There are many theories of moral development that attempt to provide a mechanism by which it is possible for the human to grow into socially functioning system of values.

\section{The concepts of moral development}

One of the first complete concept of moral development explaining the process of interiorization of norms and moral values was proposed by Freud. According to his theory, one of the three basic structures of personality, so-called "superego", is responsible for human morality. It is the factor that influences the development of moral behavior of the individual.

In the first years of life, the child's behavior is directed by the "id". It is the most primitive layer of the human psyche which represents all inherited and instinctive drives. At that time, the main objective of the individual is striving to satisfy any selfish needs and desires immediately. It works on the principle of "maximizing pleasure", not paying any attention to any restrictions or social requirements. 
In time, the child develops the second layer of personality - the "ego". It still seeks to satisfy their own selfish needs and desires, but in a way that is adapted to the requirements of the surrounding reality. It is less impulsive and more consciously directs its conduct. Actions of both id" and, being in its service, "ego" is subordinated to biological necessities. Therefore, from an early age of a child, the society seeks to limit its freedom to satisfy these primitive instincts. It is done through a system of specific barriers that are in the form of moral norms and rules. Their purpose is to protect the interest of the whole society, to enable collaboration between people, and thus to protect and ensure the existence of all individual entities (J. Trempała, 1993). Under the influence of such social impact, a child develops the third layer of personality, referred to by Freud as the "superego". It appears at about 4-6 years of age. The main mechanism for the development of "superego", and hence of moral development - according to Freud - is the process of identifying a child with its parents. In the process of identifying with the parents, the child begins to imitate their parents' behavior. As a result, they assume moral rules, patterns of behavior, their attitudes and moral standards. Simultaneously, they assimilate the standards that apply in a particular culture and society. They are "internalized in the superego in the form of certain attitudes or beliefs" (J. Trempała, 1993). In time, the "superego" also includes moral rules that come from other significant individuals that the child identifis itself with such as teachers, peers or admired people. "Superego" is, therefore, a set of rules and moral norms assimilated by an individual, forming mainly representation of parental requirements. This structure is, to some extent, unconscious. "It consists of two parts. The first of them, the perfect I groups the ideas that the child has on good behavior, that is, such that would be praised by the parents and other significant people. It will decide on what action is right and proper. The second constituent, so-called Conscience, contains a system of internalized prohibitions. Its task is to censor immoral content coming from the $i d$, thus preventing them from entering into the ego consciousness (A. Birch, T. Malim, 1998, p.88).

"Superego" is therefore responsible for exercising internal control over the behavior of the child. Its action involves strong emotions. When a child wants to break moral rules in a manner that is inconsistent with the internalized principles, their "conscience" emerges which evokes the feeling of guilt and shame. However, when the child behaves in accordance with the internal rules of morality, what appears is the feeling of pride and satisfaction resulting from a job well done. The child usually avoids negative experiences and, therefore, "tries to conform to the accepted rules, inhibits the impulses that are incompatible with those rules and prevents them from entering their consciousness" (B. HarwasNapierała, J. Trempała, 2002, p.109).

According to the psychoanalytic concept, the man who has a strong and sensitive "superego", does not want to experience feelings of guilt and inferiority. Therefore, they put their own behavior under conscious control to avoid parting with the "superego" internalized moral rules" (M. Łobocki, 2002, p.54). Strong 
"superego" develops in children who "come from families with strong emotional ties between parents and children, where both parents represent high moral standards and show a consistent dissatisfaction with their violation by their child" (J. Trempała , 1993, p. 22).

The most important element in Freud's theory is drawing attention to the importance of early child-parent relationships and their importance in shaping the moral development of the child. It largely depends on parents which standards are internalized by the child and what patterns of behavior they adopt. In addition, Freud pointed at identification as an important mechanism responsible for the acquisition of the rules of conduct by the child.

Learning theorists believe that moral development, especially the development of moral behavior of people, happens mainly due to the impact of external environmental factors. They assign less weight to internal conditions, genetic factors or human cognitive abilities. In their view, moral development is the result of individual learning of the norms and values that apply to a given environment. However, moral behavior acquired by them is the result of processes such as classical conditioning, instrumental conditioning, and observational learning.

Some of the representatives of learning theory assumed that the development of moral behavior is the result of processes of classical and instrumental conditioning. Such views were propagated, i.a. by M.J. Eysenck, who considered the moral development in terms of the conditioned reflex.

Small children often act in a socially reprehensible manner by, e.g. lying, stealing, behaving aggressively or destructively. They would be punished by their parents or other persons for these antisocial acts by: a slap, revoking a privilege, denying various types of pleasure or rebuke. These penalties induce various negative feelings in the child: pain, fear or shame. Frequent co-occurrence of "a neutral stimulus (associated with the activity performed) with the unconditioned stimulus (i.e. penalty) provokes an automatic fear response conditioned in such a way that whenever there is a previously neutral stimulus, it begins to trigger this reaction by itself" (J. Trempała, 1993, p.24). As a result of the generalization process, unpleasant feeling of anxiety also triggers stimuli which, to some extent, are similar to that of a conditioned stimulus.

M.J. Eysenck believed that the generalization process can be facilitated by "labeling" reprehensible factors by the parents, i.e. by characterizing them as "bad". This makes the anti-social acts with the "label" are treated by the child in the same way, and are associated with adverse experiences. As a result, "not only real attempts, but the mere thought of any of these activities immediately evoke fear, preventing the individual from misbehaving" (B. Harwas-Napierała, J. Trempała, 2000, p.111).

According to the views of M.J. Eysenck, conscience is a fear-conditioned response to situations and behavior of a certain character. However, individual differences between people in the power of conscience, are caused by their 
susceptibility to conditioning, which is inherited. Acquisition of human moral behavior is, therefore, dependent to a large extent on human ability to condition: the greater this ability is, the easier their assimilation.

In terms of conditioning theory, moral principles acquired by an individual can thus be reduced to a learned response to avoid penalties and the pursuit of rewards. However, other researchers such as A. Bandura and R. Walters argued that moral development and acquisition of moral behavior by an individual happens through imitation. It is a mechanism that is based on observing others and repeating sounds and movements similar to those made by an observed person, i.e. the model. The child imitates the behavior of their parents, friends and other people and thus assimilates, according to A. Bandura and R. Walters, its own patterns of moral behavior. Impact of the model on the observer's behavior may be the result of:

- the effect of facilitation (an example is the reaction of yawning at the sight of a yawning person),

- alternative reinforcements that inhibit or trigger reactions,

- observational learning.

For the moral behavior development, the most important are the behaviors that result from alternative reinforcements and observational learning. In his research, A. Bandura showed that observing the behavior of others and the consequences that are their result, leads to an increase or a reduction in inhibiting trends in the observer before taking similar action. If the negative behavior of the model is punished, the observer will refrain from misbehaving in a situation similar to the model. However, the observation that the model escaped reprimand or was rewarded in some way for their bad behavior, makes the observer's tendency to refrain from similar actions be weakened in the same way. This shows that „not only direct reinforcements, but also the consequences of the behavior experienced by the model, called alternative reinforcements, affect the observers' tendency to imitate" (B. Harwas-Napierała, J. Trempała, 2000, p.112).

A very important role in the acquisition of various forms of behavior is played by an observational learning. It has been noticed that children are able to reproduce the model's actions, or acquire new forms of actions by observing the model, although they do not mimic these behaviors in an overt manner at the time when these reactions occur. This applies even to those activities that do not have instrumental value to them. Children learn not only the behavior observed in a model, but also the values and the ways of solving problems that form their basis. Four interrelated processes affect observational learning: attention, retention, motor reproduction and motivation boost. According to the researchers ,model stimuli are the subject of the child's attention, they are encrypted, self-represented, decoded and reproduced according to the requirements of the current situation" (J. Trempała, 1993, p.29). Their role is to mediate between the model situation and the behavior displayed by an individual. 
J. Piaget, the founder of the cognitive-developmental theory of moral development, believed that the mechanism of moral development is not so much passive assimilation of ,ready and given moral rules of society by the child, but rather an active organizing and reorganizing of moral knowledge that the child gathers in social interactions with peers and adults" (B. Harwas-Napierała, J. Trempała, 2000, p.113).

According to J. Piaget, the main source of moral development and the driving force of man is the transformation of his cognitive structures. More and more complex thought operations make it possible to know the expectations and standards prevailing in the society, better and better moral reasoning, or understanding of moral concepts, more mature moral judgments and evaluations, and thus more appropriate and mature moral behavior. In the course of time, a child, due to intellectual development, understands social situations better and more adequately, possesses growing and real awareness of rules and standards prevailing in the group, and feels more and more internally compelled to defend and follow them.

According to J.Piaget, moral development is a gradual escalation of internalization processes, i.e. interiorization of already existing moral norms. It goes from the stage of moral heteronomy, when the standards are imposed from the outside, to autonomy, which is its goal, and in which the standards are considered as their own and the full achievement of which enables them to introduce certain transformations. A sense of moral obligation is formed in the human moral development. In order to achieve its appropriate level, it is necessary for the child to move through its various phases.

The first stage of moral development defined by J. Piaget is the stage of moral anomie. It falls on the period between birth and the age of 2 (M. Lobocki, 2002, p.56). At that time, people have no moral conscience whatsoever. They do not realize that others direct certain expectations or demands towards them. Moreover, they do not know that there are any moral standards or principles of good behavior. They do not feel the need or the obligation to submit to somebody else's will, or comply with any regulations or rules of conduct, especially the moral ones. A child at this stage behaves ,as they please (...) is consistent with its own feeling - beyond the reach of its own needs or behavior on the part of the environment" (M. Łobocki, 2002, p.56). When children do harm to someone, they are not able to experience a sense of guilt. According to J. Piaget, the child does not understand and cannot assess any rules of conduct, therefore, you cannot discuss moral or immoral behavior in this case. It is amoral.

The second stage of moral development is a moral heteronomy stage. It falls for toddlers, preschool and early-school age, i.e. more or less 2 to 9 years of age. At that time, little man treats standards as imposed from the outside. They are, therefore, heteronomous in their character. They are respected by the child only because of the authority of adults, and the threat of punishment for breaking them. In the early years of the child's life, interpersonal contacts are mainly limited to the contact with 
its parents. It believes in the omnipotence and absolute validity of the orders that they formulate. The child often does not understand these norms of behavior; does not consider their properness or interpret them. The rules are not the product of the child's mind; they are imposed from the outside. It believes, however, that the rules must be obeyed and there is no appeal from them. „They have the right to physical integrity, and even, to a certain extent, a sense of holiness" (M. Łobocki, 2002, p.56). A child treats them in such a way due to respect towards adults and their authority. At this stage, the individual is characterized by self-centeredness, it believes that all people have the same idea of what is good and what is bad. A good deed is the one that results from absolute obedience to adults.

A typical characteristics of this stage is the „moral realism.” In view of J. Piaget, it is ,the tendency for the child to treat the obligations and the associated values as existing in themselves, independently of consciousness and enforced, regardless of the circumstances in which the individual is involved" (J. Piaget, 1967, p.101). That reality is the result of intellectual immaturity of children, their self-centeredness which makes it difficult to distinguish between what is subjective and what is objective as well as intellectual pressure that adults exert on them.

Moral realism of children leads to recognition of all the rules by them as given from the outside, imposed by adults. Their observance is necessary because of the duty to be obedient to adults. „A good deed is the one which demonstrates obedience to the rule, or even to adults, regardless of the nature of their orders, the evil one is any deed against the rules" (J. Piaget, 1967, p.101). For children at this stage it is important to ,respect the letter and not the spirit of the rule", they do not take into account the nature of the situation or the circumstances in which they are expected to comply with those rules.

Understanding and perception of the world in a literal manner, and identifying what is good only through obedience to adults, makes the child feel so-called objective responsibility. It denotes ,the tendency to judge various moral situation primarily because of their objective (physical) consequences" (M. Łobocki, 2002, p.57). It does not take into account the intentions of those who act, or the motives of their actions.

Children in this period are convinced of the inevitability of punishment in case of breaching the rules set by adults. No offense can avoid deserved sanctions. J. Piaget defines this attribute in children as "a sense of immanent justice", which is associated with a belief in "the wonderful power of rules the misappropriation of which must always meet inevitable punishment" (M. Lobocki, 2002, p.57). Even if an offense has taken place in secret from the adults, the child is still convinced that the perpetrator will suffer the punishment, because no violation of moral rules can avoid deserved sanctions.

At about 7 years of age, people enter a transitional stage of moral development. Slowly they are beginning to realize the existence of rules and standards. They begin to "judge actions by their compliance with the standards of conduct 
required by the adult social environment" (B. Harwas-Napierała, J. Trempała, 2000, p.114). They also take into account the intentions of those who act. At that time, however, they are still dominated by the belief that the rules are inviolable, and their modification is synonymous with the offense.

Around the beginning of adolescence, at about 12 years of age - according to J. Piaget - heteronomous morality of "pressure and authority" begins to transform into "moral autonomy". At this stage, girls and boys assess the rules that are imposed on them by adults in a more critical way. They follow the rules, not because they are afraid of sanctions for their violation or they are convinced of the need to be obedient to adults. They no longer regarded those rule as unchangeable. They recognize that they can be modified in certain situations. They are aware that "in the matters of morality, different opinions or positions worthy of attention can exist as well" (M. Łobocki, 2002, p.58).

At the stage of autonomy, young people focus on universal moral problems, rather than on what concerns them from the moral point of view. They demonstrate "considerable increase in moral reasoning, it is evolving to focus on supposedly irrefutable objective rules and consequences (which is typical especially for the stage of moral realism) to ever wider and more flexible view of the world and the people" (M. Łobocki, 2002, p.58). Autonomy stage occurs mainly in those children who have not experienced excessive pressure on the part of adults and had many opportunities to interact and cooperate with others. As a result, they come to believe that the behavior is good from a moral point of view because it does not compromise the norm, rule or principle of moral conduct which, by all means, is correct.

During this time, children establish and maintain contacts with the increasing group of peers. Their self-centeredness disappears. They begin to understand that people may have a different view and opinions on the same subject. As a result of interaction with peers, the rules are no longer regarded as unchangeable. They begin to realize that "the standard is not the rule of behavior imposed from the outside, but the result of interaction between people and the mutual agreements which may lead to a change of rules of conduct" (J. Trempała, 1993, p.43).

A human being develops a rational moral consciousness. Moral realism is replaced by relativistic attitude to the world and standards. In the assessment of someone's conduct, they do not only take into account the physical consequences of the action and its compliance with the rules, but the most important elements are the motives and intentions of those who act. They begin to evaluate actions "in general terms of respect between people, equality, justice in the context of various aspects of the moral situation"(B. Harwas - Napierała, J. Trempała, 2000, p.114).

By studying moral development of a human being, L. Kohlberg found that you could describe it in more detail than J. Piaget did. He distinguished more stages of development than Piaget. In moral development of a human being L. Kohlberg distinguished three levels: preconventional, conventional and postconventional 
level. Each of them consists of two development stages. Individual steps are formed on the basis of more and more complex moral perspectives. The next stage can be achieved only if the lower stage is accomplished. Each level of moral development highlighted by L. Kohlberg is characterized by a different type of relationship between the individual and the rules of social life and expectations and demands of others directed towards an individual.

The first level includes preschool and early-school age children. At this stage, the individual takes into account only their own point of view. They do not understand and cannot see the needs of others and their mental states. They are guided only by self-interest, the satisfaction of their own needs. They do not understand other people's expectations, rules, and standards. It is, therefore, difficult at this time to talk about the morality of a child because of their behavior in this age group depends on external conditions, and the rules and standards are treated as imposed.

Within the preconventional level, L. Kohlberg distinguished two stages. The first stage, according to his idea, is the stage of punishment and obedience, also known as heteronomous morality. During this period, the child observes the moral standards because they are imposed by adults and sanctions and penalties are imposed for their breach. The child is convinced of the need to be obedient to authority and the need to comply with them. It believes that it is the right thing not to harm others in order to avoid punishment. Actions are perceived as bad in terms of their physical consequences. During this time, children are self-centered, they do not understand and do not see and do not take into account the needs of other people. Everything is assessed only from their own point of view. In their actions, they take into account only their own benefits. They treat moral rules as literal and absolute.

The second stage is the stage of instrumental relativism or instrumental-hedonistic morality. At that time, the child is convinced that good behavior is the one that satisfies their own interests and needs. The actions may be beneficial to other people, but only if those benefits are "subject in almost equal measure to the personal well-being of the child" (B. Harwas-Napierała, J. Trempała, 2000, p.116). The children respect the rules and moral standards in so far as it brings some benefits to themselves. At that time, the child begins to realize that other people have their own point of view, their needs and their interests. But it still cannot empathize with someone else's position. It is also aware that their interests are not always in harmony with other people, that they may be in conflict. At this stage of moral development, the children can work with their peers on the basis of the transaction, i.e. "concluding agreements aimed at specific benefits especially for themselves." They admit resolving a conflict of interest as a compromise (equal sharing, exchange, contract).

Conventional level occurs in children between 13-16 years of age. At this stage of moral development internalization of social norms and rules takes place. 
They like the perspective of a community member. Morally right actions are considered those that are in accordance with the applicable standards in the community, and the rules. Morality consists of a socially shared system of moral principles, roles and norms. This level comprises another two stages of moral development. The first one is a "good boy / girl stage", otherwise known as interpersonal conformity stage, or conformist morality. During this period, the child is convinced that morally good behavior is the one that has the approval of the majority of people. In their interpersonal relations they are likely to be guided by universally recognized rules of moral conduct. What is important for the child is to be a "good girl" or a "good boy", which means behaving as others, especially the closest to a child, expect it. Being good is "acting with good motives, showing concern and care for others, maintaining good relations, care for the maintenance of mutual trust and respect" (J. Trempała, 1993). In their life, they are guided by the principle: "Behave towards others as you would like others to behave towards you." Therefore, they care to maintain good relations with others based on mutual trust, loyalty and respect. At that time, a human being assumes the attitude of conformity, uncritically surrenders to the expectation of others. They attach great importance to being good, because they want to gain recognition and approval of the people whom they contact at all costs. They assess an act as good or bad no longer according to its physical consequences, but taking the intent of the person who acts into account. They believe that reaching agreement with another person is more important than self-interest. At this time, the most important thing is the behavior that leads to "maintaining good relations with other people and getting their approval and satisfaction when you help them" (M. Łobocki, 2002, p.61). A person at this stage does not have generalized perspective of a social system.

The next stage in the development of human morality is the stage of law and order, otherwise known as the stage of a normative system morality. At that time, the individual shows a deep respect for authorities and the need to comply strictly with them. It attaches great importance to the established legal and social order which contributes to the smooth and proper functioning of a group or a society. According to the individual, the law should always be upheld; an exception can be made only in extreme situations. It is important to act in accordance with established social norms and such behavior that contributes in some way to the well-being of the group, institution or a society. The individual believes that the "universally recognized rights and duties are to guard social law and order in the broad sense, and thus ensure proper functioning of both the larger human community and particular groups or institutions" (M. Łobocki, 2002, p.61). It recognizes that "the needs of the individual are not more important than the maintenance of social order" (R. Vasta, M.M. Haitham, A.S. Miller, 1995, p.485). Social order is the highest value. Responsibility becomes important as well as doing duties, and obligations, to which one expressed their consent. Moral behavior is caused by an internal imperative of conscience. 
Postconventonal stage is the highest level of human moral development. It appears no earlier than at about 16-20 years of age. This level is re-admission of an individual's point of view, the dominant perspective is the one of general values and moral principles accepted by a particular individual that should apply every time and everywhere. People at the postconventional level understand and generally accepted social rules, but acceptance is based on the formulation and respecting the moral rules (principles), which can sometimes come into conflict with social conventions and, when that happens, people at the postconventional level choose general moral rules.

The first stage within the level (and the fifth stage of moral development) is the stage of the social contract or the moral rights of the individual. A person who is at this level is characterized by a concern for the "values important from a social point of view," or those that are important for society as a whole and for fair moral order. It is also important to ensure respect for oneself. At this stage of moral development, a person begins to be aware that different people respect different values and opinions, and that most of them are relativized to the group that the person belongs to. These rules should be observed because they are the result of a social contract. However, there are values and rights which should be respected in any society regardless of their views and opinions of the majority. Standards and legal rules are important and valid only when they secure and protect the social good as well as these fundamental principles and human values. Morality of an individual at this stage is subordinate to the defense of fundamental and inalienable universal rights. The person is aware that "sometimes a moral and legal point of view may remain in conflict" (A. Birch, T. Malim, 1998, p.93). The person believes that the purpose of the social system is to protect these rights, the defense of the individual freedom and not the limitation of them. If the social system is inconsistent with these values, it should be changed. The person is then convinced that the acts that harm society or affect the person's existence, cannot be called moral even if they comply with the law.

The last stage defined by L. Kohlberg is the stage of universal ethical principles. At this stage of moral development, the right action is the one that is done under universal ethical principles generalized by the individual. These include, among other things: justice, equality, human rights and honesty. All of them are considered to be the highest values just as life. A person at this stage of moral development feels personally obliged to act in accordance with them, as well as act for their defense. The main factor governing the conduct is "conscience whose important point of reference are universal norms, rules, principles or moral values" (M. Łobocki, 2002, p.61). Laws and agreements are respected in a society only when they grow out of those universal ethical principles. If the law affects any of them in any way, the right is not granted to the law, but moral values. The possibility of breaking the law to defend these universal principles is taken into account. A person who lives in harmony with these timeless, universal ethical standards believes that "everyone has their value and should be respected regardless of the 
views and features that characterize them" (R. Vasta, M.M. Haitham, A.S. Miller, 1995. p.486). They act morally because they are self-confident "about the accuracy or reliability of any moral precepts of universal scope and purpose of complying with them in the full sense of personal responsibility for it" (M. Lobocki, 2002, p.62). It is believed that everyone "should act so as to maximize well-being and the quality of life of all people and provide them with the conditions for the maximum freedom that is compatible with the same freedom of others" (B. HarwasNapierała, J. Trempała, 2000, p.116

As noted by L. Kohlberg, the stage of universal ethical principles is accomplished by only a few individuals. Thus, moral development proceeds according to certain defined phases. In each of them, a person cannot stop without reaching the next, higher stage, recourses are also possible. The way that individual moral development progresses depends on the intellectual abilities, the level of knowledge and understanding, personal emotivity, volitional dispositions, social experience, but largely on external and environmental factors, i.e. the culture of moral environment in which they live, provided models of moral behavior, recognized values, and the content and method of education.

\section{A sense of moral obligation}

In recent years, interest has grown among researchers about moral development of mentally handicapped people. Nevertheless, this sphere of their life is still not fully understood. The literature describing the issue reveals that moral development of slightly mentally handicapped people does not differ substantially from the moral development of fully intellectually able people who are at the same mental age. For both groups, it is subject to the same laws and rules. Mentally handicapped children, as well as intellectually able ones, are born amoral, and only as a result of contacts with the environment and establishing relationships, learn to distinguish good from evil, learn applicable standards and moral values which they eventually internalize and observe in their behavior.

According to the study conducted by many researchers, the development of moral awareness and practice of slightly mentally handicapped people, however, runs more slowly than those within intellectual norms. Various stages are then reached, and the development continues through adolescence, youth into adulthood. This is evidenced, according to J. Pilecki, among other things, by the results of a study by E. Barr Almagia (1982). They suggest that "the transition from the stage of heteronomous morality to autonomous morality in people with minor mental illness occurs until approximately 15 years of age" (J. Pilecki, 1986, p.551).

Similar conclusions were formulated by J. Pilecki (1986). He conducted research on the development of understanding of certain concepts (lies, justice, theft) by a slightly mentally retarded people. While collecting the research material he 
used a tool constructed by J. Piaget. Based on the types of moral judgments and assessments formulated by the subjects in relation to the individual stories, he stated that "the development of understanding of concepts takes place in the mildly handicapped as well as in normal children" (J. Pilecki, 1986, p. 558). However, it proceeds much slower if the correct understanding of the concepts occurs in fully intellectually able young people before 12 years of age, in a group of mentally handicapped people just above that age. According to the author, the cause of slow-paced moral development of persons with mental illness is "delays and disruptions of cognitive processes, particularly in the field of thinking that hinders the process of internalization or absorption of system of norms, values and rules of conduct." They make the achievement of the highest level of moral development - moral autonomy difficult to attain, but not impossible.

According to J. Pilecki, a significant negative impact on the moral development of people with slight mental illness, in addition to lower IQ, is also caused by adverse effect of the environment, bad upbringing atmosphere and a low social and cultural status of their families. Therefore, they have little opportunity to gain positive social experience and extend their moral knowledge. The author believes that by ensuring social learning to slightly mentally handicapped people and gaining more and more new experiences in interpersonal relations, can stimulate their moral development. Therefore, due to a proper "training", they can achieve such level of morality that allows them to "self-direct their own conduct, according to their personal needs and motives, but not remaining in conflict with the interests of the social group of which they are the members" (J. Pilecki, 1986, p.559).

Research on moral development of persons with mental retardation was also conducted by M. Kościelska (1984). The object of the analysis was the attitude that slightly mentally disabled children have for the value of "responsibility for the word", the extent to which they understand the need to act in accordance with this standard, whether they feel obliged to do it and how they justify it. She stated that the children under study did not significantly differ statistically from their non-disabled peers in the field of mental knowledge of the social meaning of the word "promise" and the power of moral conviction of the need to comply with this standard. There were some differences between the two groups in the types of justifications of the need to keep their word. It turned out that slightly mentally handicapped children often relied on the duties of a normative nature and had the welfare of others in mind more often than their primary school classmates who were dominated by the self-centered reasons. In both groups similar types of moral orientation appeared, coherent and incoherent. The same kinds of relationship between orientation and the degree of fulfillment of the promise of children were found, i.e., children in both groups with a coherent orientation behaved responsibly, while those with inconsistent orientation - irresponsibly. Based on the results of the tests, M. Kościelska concluded that the mechanism of moral and social development was the same in the handicapped as in fully intellectually able people. In her view, the "lack of intellectual functioning 
that decides about lowering of the intelligence level and is responsible for the difficulties at school, does not need to prejudge asocial or immoral behavior of slightly mentally handicapped children " (M. Kościelska, 1984, p. 343). She also emphasizes, as well as J. Pilecki, the dominant role of external factors related to a family and social situation for the social development of this group of children. In her opinion, their difficulty in social adaptation is caused not so much by an intellectual deficit, but poor financial situation of families, family pathology (alcoholism), low level of education of parents as well as inadequate learning conditions (frequent mismatch between training and educational methods and the characteristics of the children's development). She postulates the upbringing and education of the slightly mentally retarded people, which will allow them to use all their capabilities.

An important element of moral development is learning evaluation, and the development of the system of values, or some aims which an individual pursues in their behavior and their life. According to M. Kościelska, in the society "recognized measure of the size of a man, the measure of his humanity, is a kind of value that he realizes his life" (M. Kościelska, 1984, p. 307). Generally, the most prized are those values which take into account the welfare of another human being, their happiness, dignity, and contribute to the overall welfare.

Appreciating their importance in the life of every human being, many authors have taken to examine the values recognized by people with mental disabilities. They wanted to determine whether there are differences in values held by slightly mentally handicapped people, and their non-disabled peers. Research on this problem was carried out, inter alia, by A. Giryński (1996). Based on the results, he formulated the following conclusions:

- In terms of the choices made in moral and social values, slightly mentally disabled people do not differ significantly from their non-disabled peers;

- Young people, regardless of their level of intellectual development, were strongly positive towards the universally recognized values including: the moral authority, social activity, patriotism, creative work or love;

- Both groups expressed their disagreement with the values generally considered negative: hedonism, consumption, cunning life, misanthropy, cynicism;

- Statistically significant differences between the comparable youth were particularly apparent in relation to the values of emphasizing the importance of family life, success at work, saving and passive observation and obtaining eternal salvation. These values were more accepted by slightly mentally impaired young people;

- In both groups, the hierarchy of values was comparable. Young people, regardless of their level of intellectual development, attached the greatest importance to values such as moral authority, social activity, love, action, and patriotism;

- The system of values declared by young people remained closely linked to the behavior based on the prerogative of pro-social and egocentric principle, people with pro-social values declared the choice of universally recognized values more often; 
- Association between aggressive behavior of slightly mentally handicapped young people and the system of values that they declare was observed. Individuals with a high degree of aggressive attitudes often chose values rejected by the constructive environment.

The conclusions drawn by the author indicate that, in their lives, slightly mentally handicapped people want to realize values that are associated with the actions which are in accordance with the moral standards of honesty, fairness, love, friendship, kindness to others, and they also emphasize the value of their homeland, people and work for the good of society. As noted by A. Giryński (1996), the choice of the values which are commonly propagated by society, suggests that people with slight mental disabilities are susceptible to the constructive socialization impact of the environment. Therefore, he believes that the model of educational work in a special school should include intentional methods of forming correct patterns of life and respect for the universally respected values. $\mathrm{He}$ considers modeling techniques particularly useful for that purpose.

The world of values of slightly mentally handicapped young people was also studied by K. Chełstowski (2003). He tried to establish a hierarchy of values that these people represent and see if it differs from the "ideal hierarchy" postulated and developed by M. Scheler, the different levels of which are as follows: higher values - sacred, spiritual, lower values - vital, utilitarian, hedonistic.

The research of K. Chełstowski (2003) shows that slightly mentally handicapped young people, just like their non-disabled peers, most appreciate the value of a pro-social character (family life, love, moral authority, social activities, work, patriotism), and least those that the society considers to be negative (misanthropy, opportunism, power, passivity, cynicism, hedonistic values, consumer, cunning life). The author found that, although the hierarchy of values of slightly mentally disabled young people somewhat differs from the "perfect hierarchy" (higher, e.g. spiritual values are appreciated and lower-hedonistic, vital ones are also assessed), it exhibits a greater tendency to convergence with it than the hierarchy of intellectually non-disabled young people.

The results obtained by A. Giryński, K. Chełstowski and other authors, indicate that a slight degree of mental retardation does not have to be a barrier to access the world's values. With the proper socializing activities, the formation of "a coherent and integrated individual system of values hierarchized in accordance with the socially adopted system, which plays a fundamental role in the conditioning of socially approved behavior" is possible (M. Kościelska, 1984, p.343). This will enable slightly mentally handicapped people to be better socially adjusted and to be more fully integrated with the environment.

T. Witkowski (1967) devoted his research to another aspect of moral development of slightly mentally handicapped people, namely their moral sensitivity. He pointed to the dependence of moral sensitivity on the level of intelligence, age, individual experience of the individual and emotional factors. His findings indicate that the moral sense is slightly smaller in people with minor mental illness than 
their non-disabled peers. According to the author, it can be improved by adequate education which extends moral knowledge, points to the standards that are commonly accepted in society and teaches to distinguish good from evil.

Moral sensitivity, expressed as the degree of identification with the moral and social norms of mentally handicapped youth, was also studied by A. Giryński (1993). He found that there are no statistically significant differences in the level of this ability between boys with mild mental retardation and their intellectually non-disabled peers. However, they were found among the girls in the two study groups. It turned out that the girls with correct intellectual development identified themselves much more with moral standards providing a foundation for regulating interpersonal relationships with the environment.

The cited above studies on moral development of slightly mentally handicapped people show a lot of difficulties, but also the possibilities of these individuals in proper functioning of this sphere of life. Most authors agree that a reduced intelligence does not have to coincide with immoral behavior. By far, a more important factor that has influence on such behavior is the negative impact of family and social environment. Therefore, they stress the need for the intentional impact to be included in special education which will support proper moral development of the slightly mentally handicapped people and promote the use of their full potential.

Proper moral development of slightly mentally handicapped people, including the development of a sense of moral obligation, enables them to better adapt to society, to the expectations that it directs towards all its members. A necessary condition for the proper adaptation to the requirements of this kind is also having by the individuals elementary empathic abilities to take other people's roles and understanding of the expectations of others (J. Trempała, 1993, p.69).

In order to know the level of the sense of moral obligation by slightly mentally handicapped young people, the "Scale to test the sense of moral obligation" of school children was used, developed by R. Rożeńska. By creating a tool, the author assumed that the sense of moral obligation consisted of: recognizing the moral problem in a given situation, feeling the need to resolve the issue in accordance with a recognized system of values, selecting or formulating guidelines for action in a particular situation, or a moral standard. In order to study the level of the sense of moral obligation understood in this way, 28 images from R.W. Pickford technology were selected. Each of them presents the situation of everyday life. They were interpreted in such a way that the event described on the image reflected the situation which required specific behavior taking into account specific attitude to a moral standard. The illustrations relate to 14 moral standards (the two images for each standard), selected from the classification of standards of M. Ossowska. "Justice," "love to your neighbor," "general benevolence", "brotherhood", "tolerance", "humanity", "protectiveness", "mutual aid", "solidarity", "morale" belong to the so-called "soft virtues ", which lead to good deeds. M. Ossowska believes that observing them mitigates relationships and prevents interpersonal conflicts. Their common feature is the fact that their practice is always associated with the benefit of others, and certainly this 
benefit is borne in their mind. The remaining standards, namely: "courage", "truthfulness", "modesty" and "honor" belong to the so-called "virtues of honor."These are the virtues that can have "their beneficial social effects" (M. Ossowska, 2000, p. 203), but most of all, they are a decoration of the person who respects them and they enhance the person's value in the opinion of the environment.

With the "Scale to test the sense of moral obligation" the respondents' attitudes to the above moral norms in two situations were assessed. After seeing the picture and hearing the description of the events that it represents, each child was asked to select one of four possible, pre-programmed behaviors. The scale to test the sense of moral obligation is standardized. It is reliable, as defined by the retest method, the factor of which equals from 0.33 to 0.99 , while for girls and from 0.11 to 0.84 for boys. Its accuracy was also confirmed.

Selection of the study group was intentional (purposeful) and considered the following criteria: age - 14-17 years, the level of intellectual development - diagnosis of a slight degree of mental retardation and a stable family situation. 91 people with documented slight mental disabilities participated in our study on the level of the sense of moral obligation of young people with mild mental retardation. The study included 39 boys and 52 girls in the age range of 14 to 17 years of age. The group of 14-15 year olds included 32 people in the group 16-17 year olds - 59 people.

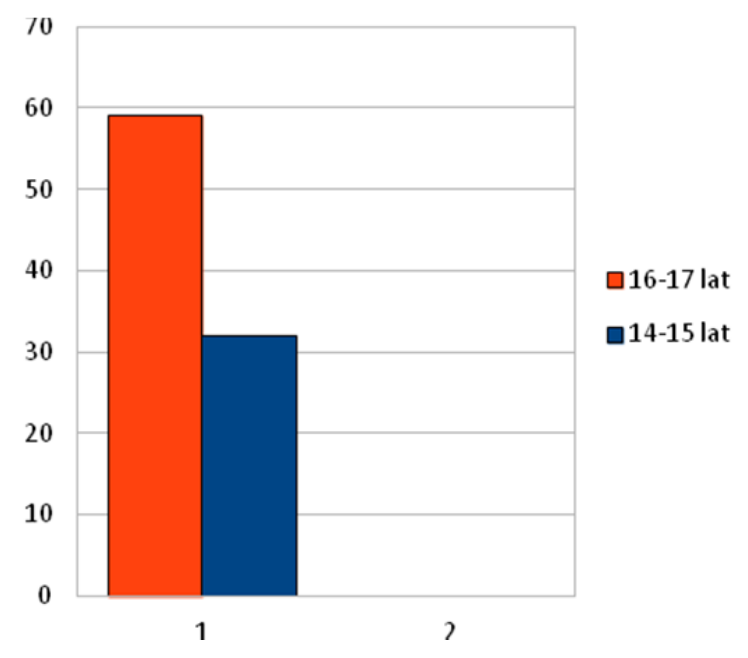

Figure 1. Structure of the young people in terms of their age

Source: Own work

Young people in the study group were the students of the $1^{\text {st }}, 2^{\text {nd }}$ and the $3^{\text {rd }}$ grade of lower secondary schools. The study was conducted in the city of Lodz. A sense of moral obligation, in other words, is a certain ability to become aware of the obligation to behave in a given situation, in accordance with professed 
moral views. It plays a huge role in the social functioning of a human being. What is particularly important is the development of the sense of moral obligation in slightly mentally handicapped people. It is significant because it affects the level of social competence achieved by those people. The higher the level of these social competencies, i.e. a special ability to take up and pursue interpersonal tasks, the greater the possibility of efficient and effective integration of people with intellectual disabilities with the environment. The main problem of the research was to determine: what is the level of the sense of moral obligation of slightly mentally handicapped girls compared with slightly mentally handicapped boys? In order to collect relevant empirical material, the degree of identification of the chosen people with moral and social standards was analyzed using the "Scale to test the sense of moral obligation" by R. Rożeńska. This tool allowed to determine, represented by teenagers, the level of general moral sensitivity, the main component of which is a sense of moral obligation. Raw results obtained by the participants of the study were converted into sten scores, and then, based on them, three levels of sense of moral obligation were established. They are as follows:

- low (sten scores 1-3),

- medium (sten scores 4-6),

- high (sten scores 7-9).

The level of sense of moral obligation in slightly mentally handicapped young people divided according to gender is presented in the table below.

Table 1 . The level of sense of moral obligation in slightly mentally handicapped youth by gender

\begin{tabular}{|l|c|c|c|c|c|c|}
\hline \multirow{2}{*}{$\begin{array}{c}\text { The level of sense of } \\
\text { moral obligation }\end{array}$} & \multicolumn{9}{|c|}{ The study group } \\
\cline { 2 - 7 } & \multicolumn{2}{|c|}{ boys } & \multicolumn{2}{c|}{ girls } & \multicolumn{2}{c|}{ total } \\
\cline { 2 - 7 } & $\mathrm{Df}$ & $\%$ & $\mathrm{Df}$ & $\%$ & $\mathrm{df}$ & $\%$ \\
\hline Low & 18 & 46.2 & 12 & 23.1 & 30 & 33 \\
\hline Medium & 15 & 38.4 & 36 & 69.3 & 51 & 56.1 \\
\hline High & 6 & 15.4 & 4 & 7.6 & 10 & 10.9 \\
\hline Total: & 39 & 100 & 52 & 100 & 91. & 100 \\
\hline
\end{tabular}

Source: Own work

Among the mildly mentally retarded boys, most subjects represented a low level of sense of moral obligation (46.2\%), somewhat less, the average level (38.4\%). The smallest percentage revealed a high level of sense of moral obligation (15.4\%). Slightly different distribution can be observed in the group of slightly mentally retarded girls. Most of them represent the average level of the sense of moral obligation (69.3\%), while the low level represented a lot less girls (23.1\%). Similarly to boys, high sense of moral obligation represented the smallest number of girls (7.6\%). 
As it can be seen from a comparison of the percentage ratios, twice as many boys have a low sense of moral obligation than girls (percentage difference is $23.1 \%$ ), the percentage difference in the average level of the sense of moral obligation is also quite significant $(30.9 \%)$, more girls than boys show an average level of the sense of moral obligation. The difference in the case of a high level of moral obligation is the lowest $(7.8 \%)$. Thus, there is a difference in the range of disclosed levels of moral obligation between slightly mentally handicapped boys and girls. This is also confirmed by comparing the average results obtained by both groups in the "Scale to test the sense of moral obligation." It turned out that the arithmetic mean of the first group (boys) is slightly lower than the average of the second group (girls).

As a result of further analysis of the empirical material, it was found that the identified differences between slightly retarder boys and girls are statistically significant.

Table 2 Statistically significant differences in the level of the sense of moral obligation in slightly mentally handicapped boys and girls

\begin{tabular}{|c|c|c|c|c|}
\hline Group & $x^{-}$ & s & t & S \\
\hline Boys & 97.35 & 10.85 & & \\
\hline Girls & 102.76 & 9.94 & -2.46 & 0.01 \\
\hline
\end{tabular}

$x^{-}$-Arithmetic mean; s-standard deviation; $t$-test result of a $t$-student; $s$ - significance level

Source: Own work

The research was conducted with the use of the "Scale to test the sense of moral obligation", in addition to determining the overall sense of moral obligation, also helped to collect data on the level of identification of the young people with different moral and social standards. This enabled revealing slightly mentally handicapped young people's attitudes to particular standards, as well as determining whether there are statistically significant differences due to the gender in terms of individual moral and social standards. The study results obtained are shown in the following table.

Table 3 Values of perceived moral norms for slightly mentally handicapped boys and girls where $p<0.05$

\begin{tabular}{|c|c|c|c|c|}
\hline Moral and social norms & $X^{-} \mathrm{M}$ & $X^{-} \mathrm{F}$ & $\mathbf{t}$ & $\mathbf{s}$ \\
\hline 1 & 2 & 3 & 4 & 5 \\
\hline Justice & $\mathbf{7 . 8 4}$ & $\mathbf{9 . 0 0}$ & $\mathbf{- 2 . 6 4}$ & $\mathbf{0 . 0 0 9}$ \\
\hline Love of neighbor & $\mathbf{6 . 5 1}$ & $\mathbf{7 . 3 0}$ & $\mathbf{- 2 . 0 4}$ & $\mathbf{0 . 0 4 4}$ \\
\hline Benevolence & 7.28 & 6.80 & 1.04 & 0.300 \\
\hline Brotherhood & $\mathbf{6 . 2 5}$ & $\mathbf{7 . 0 3}$ & $\mathbf{- 2 . 0 0}$ & $\mathbf{0 . 0 4 7}$ \\
\hline
\end{tabular}


Table 3 (cd.)

\begin{tabular}{|c|c|c|c|c|}
\hline Tolerance & 6.12 & 6.50 & 0.75 & 0.451 \\
\hline 1 & $\mathbf{2}$ & $\mathbf{3}$ & $\mathbf{4}$ & $\mathbf{5}$ \\
\hline Humanism & $\mathbf{7 . 0 7}$ & $\mathbf{8 . 0 0} \mathbf{A M}$ & $\mathbf{- 2 . 3 2}$ & $\mathbf{0 . 0 2 2}$ \\
\hline Protectiveness & $\mathbf{6 . 7 1}$ & $\mathbf{7 . 8 4}$ & $\mathbf{2 . 7 5}$ & $\mathbf{0 . 0 0 7}$ \\
\hline Mutual Aid & 6.76 & 6.42 & 0.66 & 0.508 \\
\hline Solidarity & $\mathbf{7 . 1 7}$ & $\mathbf{8 . 3 0}$ & $\mathbf{2 . 7 1}$ & $\mathbf{0 . 0 0 7}$ \\
\hline Morale & $\mathbf{6 . 6 1}$ & $\mathbf{7 . 8 8}$ & $\mathbf{- 3 . 1 6}$ & $\mathbf{0 . 0 0 2}$ \\
\hline Courage & 7.74 & 7.96 & -0.55 & 0.583 \\
\hline Truthfulness & 6.05 & 5.09 & 1.60 & 0.111 \\
\hline Modesty & 7.53 & 7.71 & -0.43 & 0.663 \\
\hline Dignity & 7.61 & 7.76 & -0.31 & 0.76 \\
\hline
\end{tabular}

X̀ M-mean score of boys; $\grave{X}$ K-mean score of girls; $t$-test result of a $t$-student; $s$-significance level

Source: Own work

Statistically significant differences between slightly mentally handicapped girls and boys were found in the acceptance level of seven standards: justice, love of neighbor, brotherhood, humanism, protectiveness, solidarity and morale. The behaviors which were in accordance with these standards were chosen much more often by the girls than boys.

Analysis of the results indicates that a significant proportion, as many as $65 \%$ of the girls, declare a high level of identification with the standard of "justice". The smallest number of them revealed a low propensity to justice (7.69\%). The average level of the sense of justice was revealed by $26.92 \%$ of the respondents. A slightly different situation may be observed with the boys - here, in turn, most of them represented the average level of identification with the standard of justice (53.84\%). They expressed their high propensity to justice much less frequently than girls (35.9\%).

Slightly mentally disabled girls that were tested are characterized by a higher level of love of neighbor value than boys. Most of them revealed a high acceptance of behaviors consistent with this standard (61.5\%) and 30.7\% average. Only $7.7 \%$ showed a low level of identification with this standard. However, slightly mentally disabled boys showed lower levels of love of neighbor - majority of subjects reached the average level in the perception of this norm (69.2\%), a high level of identification was achieved by $25.6 \%$ of the respondents. Similarly to the girls, a low level was characteristic for the smallest number of respondents $(5.2 \%)$.

The standard which slightly mentally handicapped boys and girls identified themselves with, and was significantly different statistically, was brotherhood. In this case, most of the boys $(56.4 \%)$ and $50 \%$ of girls represented a low level of 
brotherhood. When it comes to the high level of the sense of brotherhood, it is dominated by girls (11.5\%), far fewer boys achieved a high level of identification with the norm $(2.6 \%)$. The average level was achieved by $41 \%$ of boys and $38.4 \%$ of girls.

Another standard which slightly mentally handicapped boys and girls identified themselves with, and was significantly different statistically, was "humanism". The largest number of boys received a low level (51.2\%), only 19.3\% of girls represented this level. The largest group of girls represented the average level $(57.6 \%)$, the average level in boys amounted to $20.5 \%$ of the respondents. However, more boys (28.2\%) than girls (23\%) represented a high level.

Statistically significant differences between slightly mentally handicapped girls and boys were also found in the perception of the protectiveness standard. In this case, both genders represented the average level to a greatest degree $-61.6 \%$ of girls and 59\% of boys. Significant differences can be observed in the obtained high and low levels. The low level of perception of protectiveness standards represents $35.8 \%$ of boys and $19.2 \%$ girls only. The high level of protectiveness is represented by $19.2 \%$ of girls (the same number of girls represent low level) and only $5.1 \%$ of boys.

Another moral standard in which statistically significant differences were found in its perceptions by slightly mentally handicapped girls and boys is solidarity. Much larger percentage of girls (46.1\%) expressed a high level of acceptance in accordance with this standard, only $12.8 \%$ of boys represented a high level. The largest number of boys (56.4\%) represented the average level of identification with the norm of solidarity, the girls' figure represented $30.8 \%$ of the respondents. Low level of acceptance of behavior consistent with this standard was represented by $23 \%$ of girls and $30.8 \%$ of boys.

The standard which the examined slightly mentally handicapped girls and boys identified themselves with in a different way and, therefore, statistically significant differences appeared, is morale. Definitely a higher percentage of boys (48.8\%) than girls $(23.7 \%)$ expressed a low level of acceptance of behavior consistent with this standard. Girls, to a significantly greater degree, expressed a high level of identification with the norm (27\%), only $5.1 \%$ of boys achieved such results. The average level of identification with the morale standard was declared by $50 \%$ of girls and $46.1 \%$ of boys.

In the light of the results of research, it can be stated that gender is a conditioning factor in the level of the sense of moral obligation in slightly mentally handicapped youth. Girls and boys of this group differ in a statistically significant way in terms of the level of this disposition. What it means is that the hypothesis which assumes that gender is a factor differentiating the level of the sense of moral obligation has been verified positively. It transpired that girls identified themselves with the majority of moral and social norms to a greater extent. This may be the result of their rapid pace of both physical and mental development. 
The subjects were in adolescence, which is the age at which the disproportions between the sexes are the most visible.

The authors involved in the study of morality often emphasize its dependence on age, stage of human development and educational environment in which the young person lives. These studies have usually involved people with normal intellectual development. Therefore, the decision was made to verify whether a similar relationship exists in the slightly handicapped group. The present study sought to determine whether age is a factor differentiating the level of the sense of moral obligation. The first group included young people aged 14-15, the other was in the 16-17 age bracket.

Table 4. The sense of moral obligation vs. the age of the young people

\begin{tabular}{|c|c|c|c|c|}
\hline \multirow{3}{*}{ PPPM } & \multicolumn{4}{|c|}{ AGE } \\
\hline & \multicolumn{2}{|c|}{$14-15$} & \multicolumn{2}{|c|}{$16-17$} \\
\hline & df & $\%$ & df & $\%$ \\
\hline LOW & 5 & 15.7 & 25 & 42.4 \\
\hline MEDIUM & 25 & 78.1 & 26 & 44.1 \\
\hline HIGH & 2 & 6,2 & 8 & 13.5 \\
\hline
\end{tabular}

Source: Own work

The analysis of the data presented in Table 4 shows that only $15.7 \%$ of people aged 14-15 accounted for the low level of the sense of moral obligation; however, the situation looks completely different for older students - here, as much as $42.4 \%$ achieved a low level of the sense of moral obligation. The average level of the sense of moral obligation was represented by as much as $78.1 \%$ of the young people aged $14-15$, and much less $-44.1 \%$ of young people aged 16-17. The situation is somewhat different in the case of a high level of the sense of moral obligation - it is represented by $13.5 \%$ of young adults, and only $6.2 \%$ of young people aged 14-15. The differences in the level of the sense of moral obligation, older youth (16-17 years of age) and younger (14-15 years of age) showed that there was a significant correlation between the two variables (the age and the sense of moral obligation). The correlation between the level of the sense of moral obligation of slightly mentally handicapped young people and their age was to determined with the use of appropriate statistical techniques. Therefore, Pearson's correlation coefficient was determined. The correlation coefficient can take values between -1 to 1 . Depending on whether the value is closer to -1 or loser to 1 , a negative or positive correlation between the variables is referred. The advantage of the correlation coefficient that was used is the fact that it determines the direction of a possible correlation between the variables, as it measures the 
linear correlation. A positive value of $\mathrm{r} x y$ indicates that the dependent variable grows with the increase of the independent variable. If it takes a negative value, this means that the increase in the independent variable leads to a fall in the value of the dependent variable.

Table 5. The correlation coefficient between the level of the sense of moral obligation and age in slightly mentally handicapped youth, where $p<0.05$

\begin{tabular}{|c|c|c|c|c|c|c|c|}
\hline variable r & justice & $\begin{array}{c}\text { love of } \\
\text { neighbor }\end{array}$ & $\begin{array}{c}\text { general } \\
\text { benevo- } \\
\text { lence }\end{array}$ & $\begin{array}{c}\text { brother- } \\
\text { hood }\end{array}$ & tolerance & humanity & $\begin{array}{c}\text { protec- } \\
\text { tiveness }\end{array}$ \\
\hline Age & -0.01 & $\mathbf{( 0 , 2 5 )}$ & 0.05 & 0.04 & 0.05 & 0.16 & -0.15 \\
\hline
\end{tabular}

\begin{tabular}{|c|c|c|c|c|c|c|c|c|}
\hline variable & $\begin{array}{c}\text { mutual } \\
\text { help }\end{array}$ & solidarity & morale & courage & $\begin{array}{c}\text { truthful- } \\
\text { ness }\end{array}$ & modesty & dignity & total \\
\hline Age & -0.15 & -0.10 & 0.02 & -0.10 & -0.13 & $\mathbf{- 0 . 2 9} *$ & $\mathbf{- 0 . 3 9} *$ & $\mathbf{- 0 . 2 1} *$ \\
\hline
\end{tabular}

Source: Own work

The value of the Pearson's correlation coefficient between age and the level of the sense of moral obligation in slightly mentally handicapped youth is $\mathrm{r} x \mathrm{xy}=$ $-0.21, p<0.05$.This result is statistically significant. The correlation is negative, that is, the older the children, the lower the level that represents the sense of moral obligation. Perhaps this is a result of the adverse impact of the environment, poor educational atmosphere and low social and cultural status of their families. The difference between young people aged 14-15 and 16-17 in the perception of moral obligation is statistically significant. The older the child is, the longer inefficient educational environment affects them.

Pearson's correlation coefficient between age and the "dignity" standard was rxy $=-0.39, \mathrm{p}<0.05$ due to the fact that among the studied variables, the average degree of correlation exists, which is statistically significant. This means that older children identify themselves less with the "dignity" standard than the younger ones. This may be due to the fact that older children acquire patterns of the educational environment where, in order to achieve personal benefits, their values must often be compromised.

Pearson's correlation coefficient between age and the "modesty" standard was $\mathrm{r} x y=-0.29, \mathrm{p}<0.05$, which means that a weak degree of negative correlation exists between the studied variables but it is statistically significant value. This implies that young people aged between 16-17 identified themselves less with the "modesty" standard than their younger representatives. This may be due to 
a greater willingness of older children to draw attention, the need to be noticed by the nearest and dearest as well as friends.

Pearson's correlation coefficient between age and standard of "love of neighbor" was $\mathrm{r} x y=-0.25, \mathrm{p}<0.05$, which means that a weak degree of negative correlation exists between the studied variables but it is statistically significant value. It implies that a group of young people aged 16-17 identified themselves less with the "love your neighbor" standard than their younger friends. This may mean that it is a consequence of a longer stay in the pathological environment where interpersonal ties are not the basis of social life.

Thus, older adolescents identified themselves less with the norms of justice $(\mathrm{r} x y=-0.01)$, humanism $(\mathrm{r} x y=-0.16)$, protectiveness $(\mathrm{r} x y=-0.15)$, mutual help $(r$ xy $=-0.15)$, solidarity $(r$ xy $=-0.10)$, courage $(r x y=-0.10)$, truthfulness $(\mathrm{r} x y=-0.13)$ than their younger friends.

The positive value of the Pearson's correlation coefficient of a low degree of correlation was observed in the perception of the following moral standards: general benevolence $(\mathrm{r} x y=0.05)$, brotherhood $(\mathrm{r} x y=0.04)$, tolerance $(\mathrm{r} x y=$ $0.05)$ and morale $(\mathrm{r} x y=0.02)$.This means that older mentally handicapped youth (16-17 years) is more likely to identify themselves with the above mentioned standards than their younger counterparts.

\section{Summary}

The results of own research indicate that there was a correlation between age and the level of the sense of moral obligation of slightly mentally handicapped young people. It turned out that this relationship is a negative one - the older the youth, the less they identify themselves with various moral standards. It can be assumed that it is a consequence of poor educational atmosphere, adverse impact of the environment, or a low social and cultural status of the families of the slightly mentally handicapped young people. The study aimed to reveal the level of the sense of moral obligation in slightly mentally handicapped youth. The results provide the basis for conclusions.

Slightly mentally retarded adolescents are characterized by a moderate level of the sense of moral obligation. This shows the great potential of this group for interiorization of moral standards and to meeting the needs subordinated to these standards of conduct. The average level of the sense of moral obligation may indicate not a very high moral culture of the family environment of slightly mentally handicapped young people and too little a role of the family environment to deploy it to act in accordance with moral and social norms.

Slightly mentally handicapped girls represent a higher level of the sense of moral obligation than boys. The explanation of this phenomenon may be that the 
mental and emotional development of girls is faster than the development of these areas in boys. These differences in emotional maturity are most evident during adolescence. Therefore, it may be assumed that the studied boys will soon reach a similar level of the sense of moral obligation as their female counterparts.

There appeared a correlation between age and the level of the sense of moral obligation in slightly mentally handicapped young people. Younger adolescents (14-15 years of age) represented a higher level of the sense of moral obligation than their older (16-17 years of age) friends. Looking for reasons, we may assume that this is a consequence of poor educational atmosphere, adverse impact of the environment and a low social and cultural status of families of slightly mentally handicapped young people. The study confirmed the view of many researchers dealing with this issue - we are all born amoral and during the process of socialization we learn the proper conduct, slightly mentally disabled children often come from dysfunctional families where there are no relevant moral standards.

Intellectually disabled young people in spite of mild intellectual deficits can develop their interpersonal relations based on moral norms valued in society. The forms of behavior declared by them in different situations enforcing a moral choice indicate some potential opportunities that lie in this group. It can be assumed that the group is prone to pro-social actions that arise, amongst others, on the basis of moral sensitivity. This thesis is supported by the studies of A. Giryński (1989) and M. Kościelski (1985) on the readiness of slightly mentally handicapped young people to social activities.

On the threshold of the twenty-first century, the aspirations of the changing world are trying to destroy the accepted hierarchy of values as a liberation from the constraints and standards. Unbalanced system of values, however, cannot become a normal human living environment. Particular risk concerns the groups of sick and weak people. It is, therefore, necessary to strengthen their system of beliefs, build up a system of values and consolidate the need for attitudes connected with it. Over the centuries, the values and moral standards have often been broken, and their observance poses a problem for many societies to this day. While the changes in the system of values can be accepted, we must not accept their downfall as they constitute the basis of human existence. This is a group of values rooted in the natural law, values that protect life and enable people to function in accordance with their own beliefs and the communities that they live in. We also know that we always learn to act in accordance with the given standards through observation and imitation. That is why it is important to educate slightly mentally handicapped young people in accordance with the integration and standardization principles. Family environment and parental attitudes of parents of slightly mentally handicapped children are of great importance. Parents play an important role in the integration of the young person and the environment. Slightly mentally disabled children learn by imitation, a special education teacher is also an important person in the assimilation of moral norms. This person's attitude and setting 
the example is involved in the formation of moral development which is an essential part of the proper process of growing up, education and the impact on positive and negative deviations from normal development, and, therefore, is a crucial part of the education work with a mentally handicapped person.

\section{References}

Birch A., Malim T. (1998). Psychologia rozwojowa w zarysie. Warszawa: PWN.

Chełstowski K. (2003). Świat wartości młodzieży z upośledzeniem umysłowym stopnia lekkiego. Szkoła Specjalna, 4 , p. 202-211

Giryński A. (1989). Funkcjonowanie młodzieży upośledzonej umysłowo w stopniu lekkim w rolach społecznych. Warszawa: WSPS.

Giryński A. (1996). Wartości w świecie młodzieży niepelnosprawnej intelektualnie. Wybory-postawy - zachowania interpersonalne. Białystok: eRBe.

Giryński A. (1993). Nastawienie empatyczne a poziom wrażliwości moralnej dzieci lekko upośledzonych umysłowo. Kultura i Edukacja, 2/4.

Harwas-Napierała B., Trempała J. (2000). Psychologia rozwoju człowieka. Rozwój funkcji psychicznych. Warszawa: PWN.

Harwas-Napierała B., Trempała J. (2002). Psychologia rozwoju człowieka. Rozwój funkcji poznawczych, v. 3. Warszawa: PWN.

Kościelska M. (1984). Upośledzenie umysłowe a rozwój społeczny. Warszawa: PWN.

Łobocki M. (2002). Wychowanie moralne w zarysie. Kraków: Impuls.

Muszyński H. (1983). Rozwój moralny. Warszawa: WSiP.

Ossowska M. (2000). Normy moralne. Warszawa: PWN.

Piaget J. (1967). Rozwój ocen moralnych dziecka. Warszawa: PWN.

Pilecki J. (1986). Kształtowanie się ocen moralnych u upośledzonych umysłowo w stopniu lekkim uczniów klas V-VIII. Psychologia Wychowawcza, 5, p. 551-559

Trempała J. (1993). Rozumowanie moralne i odporność dzieci na pokusę oszustwa. Bydgoszcz

Vasta R., Haith M.M., Miller S.A (1995). Psychologia dziecka. Warszawa: WSiP.

Witkowski T. (1967). Z badań nad wrażliwością moralną dzieci o obniżonej sprawności umysłowej. Roczniki filozoficzne, v.15, Lublin: KUL. 